\title{
An exploration of obstacles to identity play during unemployment
}

Julia Mühlhaus, Onno Bouwmeester and Svetlana N. Khapova School of Business and Economics, Vrije Universiteit Amsterdam, The Netherlands

\begin{abstract}
Purpose - This study seeks to explore the key themes in identity play during unemployment and the potential obstacles faced by unemployed individuals.

Design/methodology/approach - This qualitative study is based on 23 interviews with unemployed individuals in Germany.

Findings - The authors identify three obstacles to identity play during unemployment: a lack of psychological safety to explore possible selves, a lack of opportunity to try out possible selves and a lack of social validation for possible selves. Several interviewees highlight the impact of social context, creating an absence of institutional support and a limited identity "playspace." As such, the authors illustrate that when faced with these obstacles, the unemployed individuals of this study predominantly focus on identity work instead of identity play. Only a few interviewees seem to engage in and sustain identity play. The authors propose that the elaborate nature of their possible selves and their focus on future opportunities may overshadow the present self and immediate obstacles.

Originality/value - The authors argue that identity play is not readily available to all individuals in all situations. Instead, they suggest that some psychologically and socially threatening contexts such as unemployment are characterized by obstacles that constrain individuals' identity play and prevent the adoption of new work identities. Hence, the authors call for a more balanced and localized understanding of identity play.
\end{abstract}

Keywords Unemployment, Identity play, Identity work, Identity threat

Paper type Research paper

\section{Introduction}

For many individuals, work is an important source of identification, reflected by the concept of "work identity" (Dutton et al., 2010). Losing one's job can be "one of the most stressful life events" (Zikic and Klehe, 2006, p. 392), negatively affecting individuals' physical and mental health (Brand, 2015). Since the unemployed may face stigmatization, a loss of social group membership and sense of self (Daskalaki and Simosi, 2018), unemployment can threaten individuals' work identity (Norris, 2016). An "identity threat" (Petriglieri, 2011) arises when individuals perceive an experience as potentially harming their identity. While an identity threat might provoke individuals to protect a threatened identity, it may also pave the way toward a new identity (ibid). Indeed, some researchers (Conroy and O'Leary-Kelly, 2014; Shepherd and Williams, 2018) suggest that individuals can recover from job loss by adopting a new work identity generated through "identity play" (Ibarra and Petriglieri, 2010). Identity play aims at (re)inventing oneself and refers to "the crafting and provisional trial of immature (i.e. as yet unelaborated) possible selves" (Ibarra and Petriglieri, 2010, p. 13). While "identity work" (Sveningsson and Alvesson, 2003, italics added) focuses on maintaining, strengthening or revising an existent identity in line with social requirements, identity play is more

(C) Julia Mühlhaus, Onno Bouwmeester and Svetlana N. Khapova. Published by Emerald Publishing Limited. This article is published under the Creative Commons Attribution (CC BY 4.0) licence. Anyone may reproduce, distribute, translate and create derivative works of this article (for both commercial and non-commercial purposes), subject to full attribution to the original publication and authors. The full terms of this licence may be seen at http://creativecommons.org/licences/by/4.0/legalcode

The authors would like to thank Editor Jim Jawahar, Associate Editor Julia Richardson and the anonymous reviewers for their constructive feedback on earlier versions of this paper.

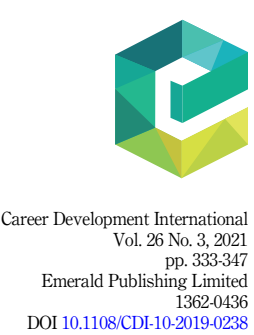

Received 3 October 2019

Revised 16 July 2020 25 February 2021 28 March 2021 Accepted 13 April 2021 
CDI

26,3

\section{4}

open-ended, guided by internal motives and based on an identity held in the future (Ibarra and Petriglieri, 2010, italics added).

Given the challenges of unemployment, it is uncertain whether or not unemployed individuals can behave so playfully. Unemployed individuals might not feel sufficiently psychologically safe, i.e. "show and employ one's self without fear of negative consequences to self-image, status, or career" (Kahn, 1990, p. 708) to engage in identity play (Ibarra and Petriglieri, 2010).

However, we lack empirical insights on identity play during unemployment and what individuals might perceive as constraining. Since adopting a new work identity requires identity play (Shepherd and Williams, 2018), it is crucial to learn more about its central dynamics. Therefore, this paper seeks to address the following two research questions: (1) What are the key themes in identity play during unemployment? (2) What are the potential obstacles to identity play during unemployment?

Based on interviews with unemployed individuals in Germany, we contribute to the literature on identity work and identity play after job loss (e.g. Conroy and O'Leary-Kelly, 2014; Daskalaki and Simosi, 2018; Shepherd and Williams, 2018). We suggest that identity play during unemployment is challenging since the unemployed in our study face three main obstacles (a lack of psychological safety, a lack of opportunity to try out possible selves and a lack of social validation for possible selves), and instead focus on identity work. We further contribute to studies on identity play (Fachin and Davel, 2015; Ghaempanah and Khapova, 2020; Ibarra and Petriglieri, 2010) by illustrating how psychologically and socially threatening contexts can make identity play more difficult. Accordingly, we call for more balanced and localized understandings of identity play.

\section{Identity play during unemployment}

Unemployment can threaten individuals' work identity (e.g. Norris, 2016), their self-definition tied to job or membership in work-related social groups or occupations (Dutton et al., 2010). Some authors (Conroy and O'Leary-Kelly, 2014; Shepherd and Williams, 2018) suggest that individuals can endure job loss by creating a new work identity facilitated by identity play. Identity play aims at exploring "possible selves": individuals' ideas of who they might become, who they would like to become or fear becoming (Markus and Nurius, 1986).

Studies on identity play (Fachin and Davel, 2015) and identity play after job loss (Shepherd and Williams, 2018) are relatively optimistic about individuals' ability to engage in such exploratory behavior. Shepherd and Williams (2018) assume that partial or full reconsideration of work identity implies creativity and pleasure. Similarly, Fachin and Davel (2015, p. 386) stress that such "imagination, dreams, and fantasies can propel change." It is suggested that in the constructive terms of a "restoration orientation" instead of a "loss orientation" (Conroy and O'Leary-Kelly, 2014) and a "promotion focus" instead of a "prevention focus" (Shepherd and Williams, 2018), individuals' emotions and regulatory foci (Higgins, 1998) can be beneficial for identity play and the adoption of new work identities.

For identity play to enable new work identities, the possible selves require provisional trial and refinement (Fachin and Davel, 2015; Ibarra, 1999; Shepherd and Williams, 2018). Individuals craft "provisional selves" (Ibarra, 1999) to test those not yet fully elaborated possible selves. This involves internal evaluations of the congruence between the individual, the provisional self and whom they seek to become. Therefore, identity play may consider the future and related aspirations but also the present and current, existing possibilities (Ibarra and Petriglieri, 2010).

Moreover, several researchers (Fachin and Davel, 2015; Ibarra, 1999; Shepherd and Williams, 2018) assume that social validation, or feedback from the social group one belongs to Ashforth (2001), plays a key role in identity play. Such external evaluations can enforce individuals' possible selves or make them refine elements of their possible selves or discard them entirely (Ibarra, 1999; Markus and Nurius, 1986). 
Shepherd and Williams (2018, p. 37) state that "unconstrained by distal goals, the individual is free to form and pursue proximal goals, such as forming and testing provisional identities enacted in identity play." However, the suggested identity threat and the social stigma inherent to unemployment may constitute considerable constraints to identity play that might be difficult to ignore. Hence, unemployment might not be a "safe transitional space" (Kets de Vries and Korotov, 2007, p. 375) or an identity "playspace" crucial for the exploration of possible selves (Ibarra and Petriglieri, 2010, p. 20 drawing on Petriglieri and Petriglieri, 2010).

It is suggested that when work identities are threatened, individuals focus on the past and present (Ibarra and Petriglieri, 2010) and engage in identity work (Sveningsson and Alvesson, 2003) to comply with image requirements (Ibarra and Petriglieri, 2010). Indeed, studies on unemployment have predominantly applied the concept of identity work (e.g. Daskalaki and Simosi, 2018; Norris, 2016). Though unemployed individuals' construction of possible selves (Markus and Nurius, 1986) has been previously referred to (Daskalaki and Simosi, 2018; Koen et al., 2016), we lack insights into the possibilities of identity play during unemployment and its potential obstacles. This study seeks to address this deficit.

\section{Methods}

\section{Research design and context}

Given this study's exploratory nature, we opted for a qualitative research design to consider the interviewees' interpretations of their experience of unemployment. The research context is Germany, where unemployed individuals are offered a job counselor and job search training. This service also often includes professional retraining and subsidized public employment (Job Center, 2020).

\section{Sample and data collection}

The sample comprises 23 long-term unemployed individuals, meaning those who have been without work for a minimum of 12 months (Bundesamt für Justiz/Federal Office of Justice, 2020). The interviewees were recruited via non-profit organizations that offer subsidized public employment to the long-term unemployed. The sample includes individuals who have been unemployed for less than three, up to more than ten years. Twenty-one interviewees are German, one is half-German/half-Bolivian and one is Columbian. We do not consider the Columbian as an outlier since she has been married to a German for over 20 years and speaks German fluently. For a balanced inquiry, both men (11) and women (12) were selected as well as individuals of different ages with diverse educational backgrounds and occupational histories (Table 1).

We conducted semi-structured interviews to understand how the interviewees had navigated their work identities during unemployment. While conducting the first interviews, it became apparent that the interviewees referred to attempts to explore possible selves and the obstacles they faced. As these themes emerged across several interviews, we inquired about them during the subsequent interviews. After obtaining consent, the interviews were recorded and transcribed. The interviews had an average duration of $57 \mathrm{~min}$ and generated 519 single-spaced pages of text. We have given each interviewee a pseudonym to ensure confidentiality.

\section{Data analysis}

We used the Gioia methodology (Gioia et al., 2013) to analyze the data. After uploading the transcripts to the software, Atlas.ti 8, we developed first-order codes, emerging from the data (see also "open coding" by Strauss and Corbin, 1990). At this stage, we manually assigned first-order codes to words or paragraphs to understand how the interviewees navigated their 


\begin{tabular}{|c|c|c|c|c|c|c|}
\hline \multirow[t]{3}{*}{$\begin{array}{l}\text { CDI } \\
26,3\end{array}$} & Interviewee & Gender & Age & Education & $\begin{array}{l}\text { Former } \\
\text { occupation }\end{array}$ & $\begin{array}{c}\text { Duration of } \\
\text { unemployment } \\
\text { (years) }\end{array}$ \\
\hline & Tuan & Male & $41-50$ & Started studies (business) & Salesman & $<5$ \\
\hline & Monika & Female & $51-60$ & Completed studies (business) & Fashion store & $>10$ \\
\hline \multirow[t]{20}{*}{336} & Carolin & Female & $31-40$ & High school diploma, started studies & Supermarket & $<5$ \\
\hline & Eckhard & Male & $51-60$ & $\begin{array}{l}\text { (law) } \\
\text { Completed apprenticeship } \\
\text { (advertising), started studies } \\
\text { (business) }\end{array}$ & $\begin{array}{l}\text { Advertising } \\
\text { manager }\end{array}$ & $>10$ \\
\hline & Andrea & Female & $51-60$ & Completed studies (literature) & Tour guide & $<5$ \\
\hline & Matthias & Male & $41-50$ & Completed apprenticeship (butcher) & Delivery man & $>10$ \\
\hline & Theresia & Female & $61-70$ & Completed studies (commerce) & $\begin{array}{l}\text { Advertising } \\
\text { manager }\end{array}$ & $>10$ \\
\hline & Gisela & Female & $61-70$ & $\begin{array}{l}\text { Completed apprenticeship (taxation, } \\
\text { accounting) }\end{array}$ & Accountant & $<5$ \\
\hline & Beate & Female & $61-70$ & Completed apprenticeship (retail) & $\begin{array}{l}\text { Retail } \\
\text { manager }\end{array}$ & $>10$ \\
\hline & Katja & Female & $51-60$ & Completed apprenticeship (archive) & Archivist & $>10$ \\
\hline & Stephan & Male & $41-50$ & Started studies (politics) & Journalist & $>10$ \\
\hline & Christin & Female & $31-40$ & $\begin{array}{l}\text { Completed apprenticeship } \\
\text { (hairdresser) }\end{array}$ & Hairdresser & $>5$ \\
\hline & Vanessa & Female & $31-40$ & $\begin{array}{l}\text { Apprenticeship (commerce), started } \\
\text { studies (communications) }\end{array}$ & Tour guide & $>5$ \\
\hline & Stefanie & Female & $41-50$ & Completed studies (archive) & Archivist & $>5$ \\
\hline & Judith & Female & $31-40$ & $\begin{array}{l}\text { Apprenticeship (archive), started } \\
\text { studies (library studies) }\end{array}$ & Archivist & $<5$ \\
\hline & Wolfgang & Male & $61-70$ & Started studies (graphic design) & $\begin{array}{l}\text { Artist, } \\
\text { graphic } \\
\text { designer } \\
\text { (freelance) }\end{array}$ & $>10$ \\
\hline & Helmuth & Male & $51-60$ & Apprenticeship (miner) & $\begin{array}{l}\text { Factory } \\
\text { worker }\end{array}$ & $>10$ \\
\hline & Sandra & Female & $41-50$ & Apprenticeship (florist) & Florist & $>10$ \\
\hline & Danny & Male & $31-40$ & $\begin{array}{l}\text { Completed studies (philosophy and } \\
\text { politics) }\end{array}$ & $\begin{array}{l}\text { Hospitality } \\
\text { employee }\end{array}$ & $>5$ \\
\hline & Frank & Male & $41-50$ & $\begin{array}{l}\text { Completed studies (literature, } \\
\text { dramatics) }\end{array}$ & Journalist & $>5$ \\
\hline & Olaf & Male & $51-60$ & Completed studies (philosophy) & Archivist & $>5$ \\
\hline & Heiko & Male & $51-60$ & $\begin{array}{l}\text { Completed apprenticeship (electrical } \\
\text { engineering) }\end{array}$ & $\begin{array}{l}\text { Electrical } \\
\text { engineer }\end{array}$ & $>10$ \\
\hline $\begin{array}{l}\text { Table } 1 . \\
\text { Sample }\end{array}$ & Dirk & Male & $51-60$ & $\begin{array}{l}\text { Completed apprenticeship } \\
\text { (construction) }\end{array}$ & $\begin{array}{l}\text { Construction } \\
\text { worker }\end{array}$ & $>5$ \\
\hline
\end{tabular}

work identities during unemployment. For example, when the interviewees mentioned specific occupations and imagined being, for example, a kindergarten teacher or graphic designer in the future, we coded for "exploring possible selves." Likewise, when the interviewees defined themselves in terms of the work role that they had before their unemployment, we added the code "adopting a former work identity."

In the second stage, we explored how theoretical categories could capture the emerging themes. Afterward, we aggregated the identified theoretical dimension to a higher level of abstraction.

These steps involved iteration between the data and the existing literature (Gioia et al., 2013). Drawing inspiration from conceptual studies on work identities after job loss (Conroy and 
O'Leary-Kelly, 2014; Shepherd and Williams, 2018), we created the aggregate dimension "perceived obstacles to identity play" with the corresponding categories "lack of psychological safety to explore possible selves," "lack of opportunity to try out possible selves" and "lack of social validation for possible selves." In line with research on identity work and play (Fachin and Davel, 2015; Ibarra and Petriglieri, 2010; Sveningsson and Alvesson, 2003), we created the aggregate dimension "identity responses," with the categories "identity work" and "identity play," to illuminate the unemployed individuals' identity trajectories.

In the final stage, we sought to understand the relationships between the dimensions (Gioia et al., 2013, p. 20). We analyzed the reason for the different identity responses by considering the nature of the possible selves and the individuals' focus on future opportunities against present obstacles.

\section{Findings}

Our conceptual model (Figure 1) integrates our codes, presented through thick descriptions from our data. We present three obstacles that seem to make identity play during unemployment difficult: (1) a lack of psychological safety to explore possible selves, (2) a lack of opportunity to try out possible selves and (3) a lack of social validation for possible selves. In this regard, the interviewees refer to the absence of an adequate identity playspace and a social context that provides negative feedback. We suggest that when facing these obstacles, the interviewees predominantly engage in identity work. Only a few of them seem to be able to focus on and sustain identity play. Their elaborate possible selves and future opportunities seem more predominant than the present self and immediate obstacles.

\section{Identity play}

In our study, identity play is most apparent in the age group 31-40, who report a shorter period of unemployment. Young unemployed might recall that they have a long working life ahead, encouraging them to explore possible selves. Moreover, given the shorter unemployment duration, they might be more hopeful than those who have experienced continuous failure to achieve reemployment. However, sustained identity play can be detected among a few older interviewees who have been unemployed for a longer period. This seems to be when the interviewees' fantasies are more elaborate in terms of the tasks that the possible self will be performing. These individuals seem to focus more on future opportunities and consider their possible selves attainable. Strauss et al. (2012) suggest that the more elaborate and accessible a future work self, the more salient it is. They suggest that the "mental stimulation of the desired future prompts envisioning and planning to achieve this future" (p. 593). Tuan, for example, explores a possible self as an entrepreneur in the food sector. He mentions specific tasks of this possible self that he likes to do and considers the possible self attainable:

I would dare to enter the tourism sector again. I had this fantastic idea: Become a tour guide. . . and I am a foodie. That would be a goal. A food truck. . When I see how people (earn money) for strange things, you know, then I say: "Well, you can do it as well." Sorry, that sounds very arrogant: "You can do it as well, and why do not you do it?". . Just to have this thought, this desire. I want to do something in order to build a future that I can grasp.

I really prefer to work with my hands; I prefer to cook or make chocolate or ice cream to downloading excel data, documents (Tuan).

He adds that he tests recipes for cooking and baking in his free time. Moreover, Tuan views his unemployment as a period for "time-out" and enjoys this phase of "refocus," underscoring his behavior's playful character: 
CDI

26,3

338

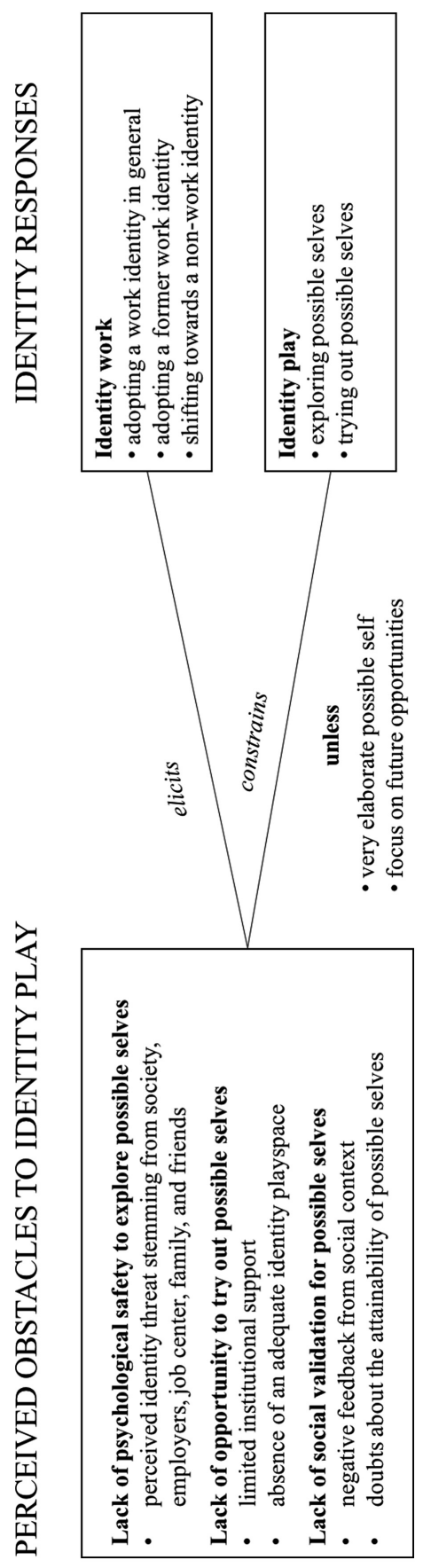

Figure 1.

Perceived obstacles to identify play during unemployment and the corresponding identity responses 
For me, this is a time to take a time-out in order to refocus and to take the energy out of myself and my environment. . .There is that word, "sabbatical", this is a word that I am consciously aware of now and also enjoying. . .I discover facets about myself that I did not know existed (Tuan).

It is positive that some unemployed individuals do not seem to discard their possible selves prematurely. Strauss et al. (2012, p. 594) suspect that elaborating a future work self allows them to maintain identity play even when some elements of it are threatened. However, as a next step, it seems important that the interviewees get the chance to enact their possible selves in a real work context; otherwise, they continue to play, "thereby delaying recovery" (Shepherd and Williams, 2018, p. 37).

Obstacle (1): Lack of psychological safety to explore possible selves. Ibarra and Petriglieri (2010) suggest that for individuals to engage in identity play, they have to feel psychologically safe. However, several interviewees do not seem to experience such safety; they report uncertainty and lack confidence due to their long-term unemployment:

I just do not have any confidence anymore. . . I fear the unknown because I have been unemployed for such a long time, and I do not have any skills or competencies to offer (Sandra).

We find that, due to their long-term unemployment, some interviewees do not seem to have the energy and motivation anymore to search for employment:

I do not dream anymore. . .I understand the unemployed who just do not have the energy anymore, those who just break out in tears (Katja).

We encountered quotes suggesting that different social contexts shape the experience of unemployment. The interviewees felt that society, employers, the job center and even family and friends consider them lazy, incompetent and low-status individuals. The corresponding quotes (Table 2) point to a perceived threat to the interviewees' work identity (Petriglieri, 2011) stemming from these social contexts.

Obstacle (2): Lack of opportunity to try out possible selves. Shepherd and Williams (2018) have argued that possible selves require provisional trial and refinement (Ibarra, 1999) for identity play to lead to a new work identity after job loss. However, many unemployed individuals in our study miss opportunities for this. In this regard, the key themes seem to be a lack of institutional support and the absence of an adequate identity playspace (Ibarra and Petriglieri, 2010, p. 20).

The data suggest that a lack of institutional support from the job center does not seem to allow unemployed individuals to learn more about the specific elements that the possible self would entail:

Primary school teaching was something that I imagined doing, and there are many providers that train for occupational change, part of which teaches you pedagogic aspects alongside the traditional apprenticeship... The problem was the cost. . .I went to the job center with the documents and said: "This would be it. This I could imagine doing, and this is a $100 \%$ guarantee. You get rid of me if this is funded. I cannot afford it." Then he looked at it and said: "With this money, I could finance a two-year commercial apprenticeship" and then the topic was done (Stefanie).

Other quotes show that employers' rejections inhibit the interviewees from trying out their possible selves in a regular work context. This corroborates Shepherd and Williams' (2018) suggestion that perceived institutional support is important for identity play.

Our data also include another example of how a lack of institutional support constrains identity play during unemployment. The job center does not seem to provide an adequate identity playspace for the unemployed to "test" their possible selves (Ibarra, 1999, p. 786). Although subsidized public employment is offered to the unemployed to achieve reemployment, they only have an assistant status and must not perform tasks that resemble a regular occupation (Bundesagentur für Arbeit/Federal Employment Agency, 
CDI 26,3

\section{0}

Employers

Job center

Family and friends
Illustrative quotes

"Everywhere you are being asked: "What do you do (for a living)?" and so on. Then they (unemployed) are ashamed. . . This does not surprise me much in this frame that society creates. . It is the generally accepted standard. It is difficult to deviate from this" (Stephan)

"I know, how tough it is, the household, being a single mom. I know that but for society, it is as follows: If you do not work and earn no money, you do not do anything" (Vanessa)

"In this protestant-shaped society, work has such a high value. You know, you are allowed to beat up your wife at home, send your children to bed without feeding them as long as you have a permanent work contract" (Olaf)

"Well, the employers probably say: "Oh my God, is she at all able to work?" or: "Is she at all still stress-resistant?" (Monika)

"Long-term unemployed. He is useless" (Helmuth)

"You just have to write "based on a job ad of the job center" or a

"recommendation from the job center", then it ends up in trash. Then they know exactly that it comes from the job center...Then he does not even look at it. . .then they think that you have been out of work for one or one and a half years and that you do not know anything at all" (Beate)

"You get the stress and the pressure from the job center...You need to prepare the people slowly because you do not have confidence in yourself anymore. . You collapse and then they say: "We knew it. He just does not manage"” (Heiko)

"At the job center. .., they had a contract with that temporary employment agency and what you feel like. It is like material. You are not somebody but you are like a table. I was also told afterwards that it was a leasing agency. That means they "lease" me. Whether they lease cars or people, regarding the handling, it is exactly the same" (Dirk)

"You have to justify why you cannot find work. It is really horrible. How much psychological stress it is if you have a letter from the job center in your mailbox. .. During the last session, they told us indirectly that it was our fault and that we would just relax on the couch all day. That was during the job search training, during the activation phase when they are actually supposed to build us up a little" (Beate)

"When you are at home with your aunts and uncles, then the problem exists and be it only for four or five times a year. It is complicated. You want to be a role model. It is not well received. . You even distance from your own family, from the wider family because this is really uncomfortable for oneself because the environment does not accept it" (Stephan)

"You just get, the bad thing is also from acquaintances, they say: "The lazy and the stupid one" or something like that, "who does not work, who is too stupid to find or search for work"” (Heiko)

"Well, a friend of mine was worried about me not doing anything for such a long time. She did not find that appropriate at all at my age. Arguments like: "You live like a retired person, you cannot do this. You are just 30." She found that really problematic" (Carolin)
Table 2.

Sources of perceived identity threat of unemployed individuals
2017). Several interviewees' accounts suggest that these characteristics of subsidized public employment make it difficult to try out their possible selves. For example, Danny highlights:

The strange thing is, according to the design and law, you have a lower status than the intern. The thing is that the subsidized public employment worker is only allowed to assist. . Given this condition, you would always be kept down, and that makes me doubt this thing. The difference is, you really start at zero, like during an internship, and the fact that you are maybe older and were further in your life makes it a bit strange to realize. That is also the difference compared to a "real" job (Danny). 
Therefore, this context seems to lead to perceived incongruence between who the unemployed are and who they want to become (Ibarra, 1999). Several interviewees highlight that the lower status and the basic tasks of subsidized public employment do not match their possible selves. Moreover, subsidized public employment might be perceived as regressing professionally (compared to one's former employment), which seems to make reemployment even more difficult. Subsidized public employment might create the feeling of a "status mismatch" (Norris, 2016), as social norms and expectations are not met.

Several interviewees also state that subsidized public employment conflicts with the expectations placed on employees in a regular work context, further constraining the availability of an adequate identity playspace. For example, some interviewees mention that hardly any requirements are placed on subsidized public employees. For example, Helmuth states that it does not matter how fast he completes his tasks, and that this would not be accepted in a regular work context. Monika adds that she did not need any specific skills (such as English or Excel) to obtain subsidized public employment at a tourist information center, but this would be different in a regular work context.

A final theme is that several interviewees criticize how they cannot develop their possible selves as the work material provided during subsidized public employment is different from the standards in a regular work context. For example, the office equipment (computers, software, copying machine) is considered outdated.

Obstacle (3): Lack of social validation for possible selves. Some authors have argued that for identity play to lead to a new work identity, social validation in terms of, for instance, positive feedback is crucial (Fachin and Davel, 2015; Ibarra, 1999; Shepherd and Williams, 2018). However, several interviewees do not seem to receive sufficient social validation for their possible selves and might no longer consider them attainable. Some share that their family and friends have lost faith in their re-employment. Others highlight that the job center or other unemployed do not believe in their possible selves. Finally, some interviewees' interactions with "regular" employees can make a possible self seem less attainable. For example, Andrea crafted a possible self as a researcher but heard from regular employees during subsidized employment that she was long-term unemployed and had no future as a researcher:

You are doing research, but you are not a researcher. You are an ant. You are doing well but... (regularly employed).

There is no future. Well, not for us (unemployed)...Like with ants, it is clear, here are the drone workers, and there is the queen. . . The (regularly) employed people at the archive. . .They signal: "You are long-term unemployed, you are nothing, you are ant." (Andrea).

The quote suggests that negative social feedback instills doubts about the possible selves' attainability and might make the individual fixate on their being unemployed. The external validation of possible selves is, then, lacking and may create incongruence between who they thought they were becoming and how the desired social context might view them. This negative feedback on possible selves seems to provoke a perceived status mismatch (Norris, 2016).

\section{Three types of identity work - when identity play becomes too difficult}

Facing these obstacles, the unemployed in this study predominantly engage in three types of identity work: adopting a general work identity, adopting a former work identity and shifting toward a non-work identity. In terms of restoring a general work identity, identity work is prevalent among the interviewees, regardless of the duration of unemployment. Meanwhile, highlighting a former work identity and switching to a non-work identity is more prevalent among individuals with more than five years of unemployment. After identity play has been repeated unsuccessfully several times, it seems that some unemployed no longer believe in possible selves. The construction of a new work identity begins to seem unlikely. 
CDI 26,3

Adopting a general work identity. Given the perceived identity threat, most unemployed individuals in our study seem to engage in identity work to restore a work identity. Their interviews demonstrate their urgency to prove to others that they, too, work. Since they do not focus on any particular type of work, we refer to the adoption of a "general work identity." The interviewees stress that subsidized public employment offers a context in which they can adopt such a general work identity:

I really felt wonderful that I was allowed to work again. . .I find it bad that it is temporary. . . The bad thing is that you are happy that you are accepted again as a human being within society, but the black hole is always there. What happens afterward? You are not caught (supported). You will again fall into "Ohh, the lazy, the stupid one" (Heiko).

Similarly, Carolin highlights that, thanks to her subsidized public employment, she "get(s) up like a normal employee in the morning and go(es) to work," and that others perceive her as "working again," as opposed to "she does not do anything." Vanessa's quote further suggests that she wants any work and has asked the job center to choose an occupation for her:

Then I said: . . . "What do you (job center) want me to do? Tell me please what I should learn. I do not care. I am flexible...Do you want me to make tax declarations? Then I will make tax declarations."

A commercial apprenticeship would be good (job center).

Then I said: "Ok, then I will do that."

But you should like that (job center).

[I said] "No, because everything that I choose, you tell me no. So please tell me what I can do". . . It was really difficult, and then I told them (the job center): "I want to work, help me. . .help me find an apprenticeship" (Vanessa).

Vanessa's experience is in line with Petriglieri's (2011) assumption that when one's identity is threatened, one's response is to eliminate the threat by purging the threatened identity. This illuminates the role that the expectations of one's social context, such as having to be employed, seem to play in enforcing given identity responses (i.e. identity work instead of identity play). However, although adopting a general work identity might be a way to protect oneself from an identity threat, one must recall that subsidized public employment is temporary and might not be regarded as a sustainable path towards regular employment.

Adopting a former work identity. Some interviewees illustrate how they engage in identity work by adopting their former work identities; they define themselves in terms of a work role from before their unemployment. For example, Christin highlights her former work identity as a hairdresser, which she calls the "dream job" she seeks to recreate:

The strategy is to go from one salon to the other and. . .try (to get reemployed), in the job that is fun, my dream job...There is this saying. . ."When you do something that you love, you will never work again”. . .I am not bored [then], but having fun. . I have six clients, and this is going to be a great day (Christin).

As Christin's experience illustrates, some unemployed individuals highlight their former work identities and daydream about performing the tasks involved in their former work role instead of engaging in identity play (see also Obodaru, 2017, on "forgone professional identities"). By recalling a former work identity, unemployed individuals might seek to address the perceived identity threat.

Shifting toward a non-work identity. We find a third type of identity work, characterized by a shift toward a "non-work identity." Unemployed individuals begin to define themselves in terms of roles beyond occupational contexts. For example, Monika's quote illustrates that she did not have the chance to try out her possible self as a marketing professional and now emphasizes non-work identities as a mother, grandmother and spouse: 
I participated in an occupational retraining program, "Marketing and Communication." That would have been a good match, but I never got a job in this field. . I was at a point that I did not want to anymore. . .I said: "You know what, your loss!". . .I am not keen on making a career anymore. I'd rather stay at home. I can keep myself busy at home very well...I have a family. I want to spend a lot of time in Potsdam with my daughter and my grandchild...I live together with someone (Monika).

Data analysis suggests that some interviewees make an identity shift (Norris, 2016) toward a non-work identity when they feel they cannot try out their possible selves. These interviewees seem to alter the salience of their identities (Bruner, 1957; Oakes, 1987), downgrading the importance of work identity and emphasizing a non-work identity. They might do so to steer away from the identity of being unemployed, thus avoiding the perceived identity threat.

The three outlined types of identity work (adopting a general work identity, adopting a former work identity and shifting toward a non-work identity) seem to focus on (work) identities of the past and present. This provides initial support for the assumption that identity work is based on the "preservation of existing identities or compliance with externally imposed image requirements" (Ibarra and Petriglieri, 2010, p. 14). While the first two types seek to restore a work identity, the third seeks to restore the overall self as the focus is no longer on work.

\section{Discussion}

\section{Theoretical implications}

This study sought to explore the key themes of identity play during unemployment and its potential obstacles. Our findings contribute to research on identity work and identity play after job loss (e.g. Conroy and O'Leary-Kelly, 2014; Daskalaki and Simosi, 2018; Shepherd and Williams, 2018).

Unemployed individuals' ability to engage in identity play. Prior research considering individuals' ability to engage in identity play after job loss has been relatively optimistic (Shepherd and Williams, 2018). Although it has been argued that identity play involves fantasies and is not goal-oriented (Ibarra and Petriglieri, 2010), our data suggest that, while identity play might have started open-endedly, for the possible self to be sustained, it is important that it feels attainable. In this study, we find that identity play during unemployment is challenged by three obstacles (lack of psychological safety to explore possible selves, lack of opportunity to try out possible selves and lack of social validation for possible selves). Facing these obstacles, the interviewees instead focus on identity work. We contribute to studies on identity play (Fachin and Davel, 2015; Ghaempanah and Khapova, 2020; Ibarra and Petriglieri, 2010) by suggesting that psychologically and socially threatening contexts, such as long-term unemployment, may make identity play difficult. Therefore, we call for more balanced and localized understandings of identity play.

Individual and contextual factors relevant to identity play. Our study suggests that both individual and contextual factors play a role in identity play during unemployment. Several interviewees' quotes show an individual loss orientation (Conroy and O'Leary-Kelly, 2014) and prevention focus (Shepherd and Williams, 2018). These individuals seem to focus predominantly on addressing the present identity threat instead of exploring possible selves. This corresponds with the argument of some authors (Conroy and O'Leary-Kelly, 2014; Shepherd and Williams, 2018) that individuals with these regulatory foci (Higgins, 1998) are unlikely to recover from job loss.

Our study also includes statements about possible selves, suggesting that some unemployed might have a restoration orientation (Conroy and O'Leary-Kelly, 2014) and promotion focus (Shepherd and Williams, 2018). We have suggested that the few unemployed who seem to sustain their identity play create elaborate possible selves in terms of specific tasks that the possible self would entail and consider their possible selves attainable. These
Identity play during unemployment

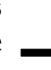


CDI

26,3

\section{4}

individuals are likely to be more "fantasy-prone" (Wilson and Barber, 1983). Research has shown how imagination can fuel the enactment of forgone identities (Obodaru, 2017). Likewise, some unemployed individuals seem to enact their possible selves in their fantasies.

Besides individual factors, context seems to play a role in identity play during unemployment. Our study suggest that social context, in terms of society, employers, the job center, family and friends, can create an identity threat to the unemployed and could prevent them from safely engaging in identity play.

Moreover, while some scholars (Fachin and Davel, 2015; Ibarra, 1999; Shepherd and Williams, 2018) acknowledge that identity transitions require social validation, this might be even more pronounced during unemployment. Since several interviewees appear to perceive an identity threat and lack confidence, positive reinforcement of their possible selves from their social context seems even more important for successfully adopting new work identities. Our data have shown how negative feedback from others on one's possible selves seems to make individuals doubt their possible selves and consider them less attainable.

Furthermore, our findings stress the importance of institutional support for identity play (see also Shepherd and Williams, 2018, p. 39). Institutional support (from the job center and employers) to help the unemployed try out their possible selves (e.g. to learn more about the specific elements that the new work role would entail) would bridge fantasy and reality (Ibarra and Petriglieri, 2010). We also suggest that several interviewees perceive a lack of institutional support when an inadequate identity playspace is provided.

The importance of an adequate identity playspace. Our findings suggest that identity play seems challenging if the unemployed do not have an adequate identity playspace (Ibarra and Petriglieri, 2010; Kets de Vries and Korotov, 2007; Petriglieri and Petriglieri, 2010). In the case of this study, this refers to subsidized public employment. An identity playspace is perceived as inadequate for identity play if the work identity associated with this space is too different from the envisioned possible selves. If individuals perceive their present work identity to be incongruous with their possible self (see also Ibarra, 1999), in terms of status, for example, it becomes difficult for them to fulfill their aspirations. Furthermore, when the work activities (in terms of specific tasks and job requirements) in the present space deviate too strongly with those of their envisioned possible selves, this also seems to impair identity play.

These findings add to the research highlighting that possible selves are not only self-comparisons with the present work identity (e.g. Markus and Nurius, 1986) but also self-definitions (Obodaru, 2017). Obodaru suggests that by daydreaming about possible selves, individuals can "mentally experience a desired future in the here and now" (see "imagined enactment," p. 543). Although our findings illustrate a few instances in which identity play is visible, we also find that such imaginings have their limits. When the present self is too different from the imagined possible self, one might no longer be able to define oneself in terms of the possible self or perceive it as attainable.

Finally, since an identity playspace does not only refer to a social and psychological space but also a physical one (Petriglieri and Petriglieri, 2010, p. 46), it is interesting to note that the physical context, in terms of outdated office equipment, is perceived by some interviewees as constraining and conflicting with the possible self's work context.

Overall, our findings suggest that for identity play to be sustained, the present identity playspace's social and physical characteristics should be similar to those of the space in which the possible self would become embedded.

This study suggests that when the unemployed perceive subsidized public employment as a quasi-work environment only, it makes it challenging to try out their possible selves under realistic conditions. This is in line with research presenting an identity playspace as a "social context that reduces disturbing affect" and facilitates the transition toward a new work identity (Petriglieri and Petriglieri, 2010, p. 44). 


\section{Practical implications}

To address the perceived identity threat (Petriglieri, 2011) described by the interviewees, we suggest job counselors offer coaching sessions focused on enhancing the unemployed person's self-confidence (e.g. uncovering strengths) and fostering a future orientation. Job support systems can further finance retraining, allowing the unemployed to consolidate their possible selves by learning more about their desired work's specific characteristics and tasks. Moreover, counselors can co-sponsor interventions in the primary labor market or selfemployment so that the unemployed can test their possible selves under realistic conditions. Those subsidies are more beneficial than public sector employment programs (Vooren et al., 2019, p. 127). By taking these actions, we suggest the perceived lack of institutional support can be mitigated and a supportive identity playspace can be cultivated.

\section{Limitations and recommendations for future research}

While our exploratory study's objective was theoretical generalization (Stake and Trumbull, 1982), future research could use quantitative designs to test our theoretical contributions. Moreover, the individuals were interviewed only once. Future studies could illuminate the nature of identity play during unemployment over time. Our findings suggest that older interviewees with a longer unemployment duration seem to engage less in identity play and more in identity work. Future studies could expand on these insights and research them in more depth. They could further capture whether identity play can be reactivated or may be lost forever. A longitudinal design could further research the effects of identity play (vs identity work) on new work identities and reemployment.

This study focused on unemployment in Germany. As identity trajectories differ across national and cultural contexts (Caza et al., 2018, p. 904), scholars could expand this research to other countries and cultures to map differences. Finally, this research covers involuntary job loss. Future research would benefit from illuminating identity play after voluntary job loss (e.g. sabbaticals). Under these circumstances, individuals might feel more in control, "safer" to engage in identity play (Ibarra and Petriglieri, 2010).

\section{References}

Ashforth, B.E. (2001), Role Transitions in Organizational Life: An Identity-Based Perspective, Routledge, New York, NY.

Brand, J.E. (2015), "The far-reaching impact of job loss and unemployment”, Annual Review of Sociology, Vol. 41, pp. 359-375, doi: 10.1146/annurev-soc-071913-043237.

Bruner, J.S. (1957), “On perceptual readiness”, Psychological Review, Vol. 64 No. 2, pp. 123-152, doi: 10. 1037/h0043805.

Bundesagentur für Arbeit (2017), "SGB II - Fachliche Weisungen zu Arbeitsgelegenheiten (AGH) nach $\S 16 \mathrm{~d}$ SGB II", available at: https://www.arbeitsagentur.de/datei/dok_ba014267.pdf (accessed 24 February 2021).

Bundesamt für Justiz/Federal Office of Justice (2020), "Sozialgesetzbuch (SGB) Drittes Buch (III) Arbeitsförderung", available at: https:/www.gesetze-im-internet.de/sgb_3/_18.html (accessed 24 February 2021).

Caza, B.B., Vough, H. and Puranik, H. (2018), "Identity work in organizations and occupations: definitions, theories, and pathways forward”, Journal of Organizational Behavior, Vol. 39 No. 7 , pp. 889-910, doi: 10.1002/job.2318.

Conroy, S.A. and O'Leary-Kelly, A.M. (2014), "Letting go and moving on: work-related identity loss and recovery", Academy of Management Review, Vol. 39 No. 1, pp. 67-87, doi: 10.5465/amr. 2011.0396.
Identity play during unemployment 
CDI 26,3

Daskalaki, M. and Simosi, M. (2018), "Unemployment as a liminoid phenomenon: identity trajectories in times of crisis", Human Relations, Vol. 71 No. 9, pp. 1153-1178, doi: 10.1177/ 0018726717737824.

Dutton, J.E., Roberts, L.M. and Bednar, J. (2010), "Pathways for positive identity construction at work: four types of positive identity and the building of social resources", Academy of Management Review, Vol. 35 No. 2, pp. 265-293, doi: 10.5465/AMR.2010.48463334.

Fachin, F.F. and Davel, E. (2015), "Reconciling contradictory paths: identity play and work in a career transition”, Journal of Organizational Change Management, Vol. 28 No. 3, pp. 369-392, doi: 10. 1108/JOCM-01-2014-0012.

Ghaempanah, B. and Khapova, S.N. (2020), "Identity play and the stories we live by", Journal of Organizational Change Management, Vol. 33 No. 5, pp. 683-695, doi: 10.1108/JOCM-072019-0238.

Gioia, D.A., Corley, K.G. and Hamilton, A.L. (2013), "Seeking qualitative rigor in inductive research: notes on the Gioia Methodology”, Organizational Research Methods, Vol. 16 No. 1, pp. 15-31, doi: 10.1177/1094428112452151.

Higgins, E.T. (1998), "Promotion and prevention: regulatory focus as a motivational principle", in Zanna, M.P. (Ed.), Advances in Experimental Social Psychology, Academic Press, San Diego, CA, Vol. 30, pp. 1-46.

Ibarra, H. (1999), "Provisional selves: experimenting with image and identity in professional adaptation”, Administrative Science Quarterly, Vol. 44 No. 4, pp. 764-791, doi: 10.2307/2667055.

Ibarra, H. and Petriglieri, J.L. (2010), "Identity work and play", Journal of Organizational Change Management, Vol. 23 No. 1, pp. 10-25, doi: 10.1108/09534811011017180.

Jobcenter (2020), "Arbeitslosengeld II/ Sozialgeld Grundsicherung für Arbeitsuchende”, available at: https://www.arbeitsagentur.de/datei/merkblatt-algii_ba015397.pdf (accessed 24 February 2021).

Kahn, W.A. (1990), "Psychological conditions of personal engagement and disengagement at work", Academy of Management Journal, Vol. 33 No. 4, pp. 692-724, doi: 10.5465/256287.

Kets de Vries, M.F.R. and Korotov, K. (2007), "Creating transformational executive education programs", Academy of Management Learning and Education, Vol. 6 No. 3, pp. 375-387, doi: 10. 5465/amle.2007.26361627.

Koen, J., van Vianen, A., Klehe, U.C. and Zikic, J. (2016), “'A whole new future' - identity construction among disadvantaged young adults", Career Development International, Vol. 21 No. 7, pp. 658-681, doi: 10.1108/CDI-02-2016-0019.

Markus, H. and Nurius, P. (1986), "Possible selves”, American Psychologist, Vol. 41 No. 9, pp. 954-969, doi: 10.1037/0003-066X.41.9.954.

Norris, D.R. (2016), Job Loss, Identity, and Mental Health, Rutgers University Press, New Brunswick, NJ.

Oakes, P.J. (1987), "The salience of social categories”, in Turner, J.C., Hogg, M.A., Oakes, P.J., Reicher, S.D. and Wetherell, M.S. (Eds), Rediscovering the Social Group: A Self-Categorization Theory, Basil Blackwell, Oxford, pp. 117-141.

Obodaru, O. (2017), "Forgone, but not forgotten: toward a theory of forgone professional identities", Academy of Management Journal, Vol. 60 No. 2, pp. 523-553, doi: 10.5465/amj.2013.0432.

Petriglieri, J.L. (2011), 'Under threat: responses to and the consequences of threats to individuals' identities", Academy of Management Review, Vol. 36 No. 4, pp. 641-662, doi: 10.5465/amr. 2009.0087.

Petriglieri, G. and Petriglieri, J.L. (2010), "Identity workspaces: the case of business schools", Academy of Management Learning and Education, Vol. 9 No. 1, pp. 44-60, doi: 10.5465/amle.9.1.zqr44.

Shepherd, D.A. and Williams, T.A. (2018), "Hitting rock bottom after job loss: bouncing back to create a new positive work identity”, Academy of Management Review, Vol. 41 No. 1, pp. 28-49, doi: 10. 5465/amr.2015.0102. 
Stake, R.E. and Trumbull, D.J. (1982), "Naturalistic generalizations", Review Journal of Philosophy and Social Science, Vol. 7 No. 1, pp. 1-12.

Strauss, A. and Corbin, J. (1990), Basics of Qualitative Research: Grounded Theory Procedures and Techniques, Sage, Newbury Park, CA.

Strauss, K., Griffin, M.A. and Parker, S.K. (2012), "Future work selves: how salient hoped-for identities motivate proactive career behaviors", Journal of Applied Psychology, Vol. 97 No. 3, pp. 580-598, doi: $10.1037 / \mathrm{a} 0026423$.

Sveningsson, S. and Alvesson, M. (2003), "Managing managerial identities: organizational fragmentation, discourse and identity struggle", Human Relations, Vol. 56 No. 10, pp. 1163-1193, doi: 10.1177/00187267035610001.

Vooren, M., Haelermans, C., Groot, W. and Maassen van den Brink, H. (2019), "The effectiveness of active labor market policies: a meta-analysis", Journal of Economic Surveys, Vol. 33 No. 1, pp. 125-149, doi: 10.1111/joes.12269.

Wilson, S.C. and Barber, T.X. (1983), "The fantasy-prone personality: implications for understanding imagery, hypnosis, and parapsychological phenomena”, in Sheikh, A.A. (Ed.), Imagery: Current Theory, Research, and Application, John Wiley and Sons, New York, NY, pp. 340-387.

Zikic, J. and Klehe, U.-C. (2006), "Job loss as a blessing in disguise: the role of career exploration and career planning in predicting reemployment quality”, Journal of Vocational Behavior, Vol. 69 No. 3, pp. 391-409, doi: 10.1016/j.jvb.2006.05.00.

\section{Corresponding author}

Julia Mühlhaus can be contacted at: j.muhlhaus@vu.nl
Identity play during unemployment 